\title{
Implementation Criteria of University Computer Education in Spain between First Experiences and the European Higher Education Space (EHES)
}

\author{
Ramon Puigjaner ${ }^{1}$ and Jordi Fornes ${ }^{2}$ \\ ${ }^{1}$ Universitat de les Illes Balears. \\ Ctra de Valldemossa, km 7.5 07122 PALMA, Spain \\ putxi@uib.cat \\ ${ }^{2}$ DAC, UPC-BarcelonaTech. \\ Campus Nord, c/ Jordi Girona, 1-3, 08034 Barcelona \\ jfornes@ac.upc.edu
}

\begin{abstract}
This paper intends to present a short overview of the different criteria used in the university environment for setting up the computer education in Spain since the first teaching experiences in this do- main to the current implementations adapted to the European Higher Education Space (EHES). Also some samples of these different curricula are presented.
\end{abstract}

\section{Introduction}

A point that is necessary to take into account is that, until the implementation of the Bologna agreement the diploma recognizing that somebody had attained some university level was delivered by the Ministry of Education and Science (MEC). In order to ensure that the knowledge delivered to the students was coherent with the diploma, the MEC required a set of conditions, variable along the years. The goal of this paper is to present the changes of criteria, the control applied to the universities by the MEC and the curricula implemented consequently.

Some historical background is needed. Computerization of Spain had begun in 1958 with two major acquisitions: an IBM 650 for RENFE, the national railway company, and an UNIVAC UCT for the JEN, the national nuclear research institution. The early push of central state, characteristic of the autarchic period, had been followed in the 1960 by a development based on private industry. With computerization ac- companying economic modernization, Spain counted by mid-1970 with almost 100,000 people working in electronic computing [29]. As happened in other countries [8], these professionals lacked a formal university education in computing and had been generally acquired their skills in computer companies such as IBM or UNIVAC. Spanish companies, relying generally on American machines, had also took advantage in the early 1960s of new installations, mostly IBM 1401 and Bull Gamma 10 , to train their employees [32], and a few began to access the profession in university computer labs, private schools and self-learning. We begin our narrative at this point, when Spanish government had just acquired an UNIVAC 1108 to process 
Ad-ministration payroll. Minister of Education, pushed by the lack of computing people among the civil servants, accepted the creation of the Informatics Institute.

No comprehensive account exists to date about the creation and evolution university studies in computing. Some articles and books had explore the topic: [33] provides a chronological listing of courses, pointing out that British universities created their stud-ies following the model started in Cambridge, while [6] analyses the role of two government agencies, the Advisory Committee on High Speed Calculating Machines and the University Grants Committee, in the establishment university-based computing facilities in the United Kingdom. Finally, William Aspray's paper [4] on the early development of computing in five American universities (MIT, Harvard, Penn, Princeton, and Columbia) has inspired international comparison, specifically in the case of French computing, which has been studied in great detail by Mounier-Kuhn $[26,27]$. In Spain, his- tory of computing has a handful of scholars [34, 31, 3, 11, 13]. Also there are some contributions made by economic historians [14, 15] and [7]. In contrast, the history of the Barcelona's School of Informatics is generally well known thanks to a commemorative work [28] and two recent papers on the history of the school's early days $[9,10]$.

The motivation of this paper is to present the evolution of the regular informatics teaching in 1969 until today. In this history the reader will find two main key actors: from one side the Ministry of Education with the goal of controlling the informatics teaching and in the other side the universities, initially each one individually and finally grouped in the CODDII (Conferencia de Decanos y Directores de Centros Universitarios de Informática, Conference of Deans and Directors of Informatics University Centres) trying to incorporate studies of something very much appreciated in eighties and nineties.

The titles of sections of this paper remark the years with significant changes in these criteria:

- Section 2: In 1969 the MEC created the Instituto de Informática (II), estrange organization delivering a diploma each year.

- Section 3: In 1976 the MEC created the Facultades de Informática transforming the delegations of the Instituto de Informática existing at that time to deliver the title of Licenciado en Informática (Licencesed in Informatics).

- Section 4: In 1992 the MEC transformed the diplomas delivered by the universities from Licenciado en Informática into Ingeniero en Informática (Informatics Engineer).

- Section 5: In 2010 all universities started to deliver the Grado en Ingeniería Informática (Bachelor in Informatics Engineering).

- Finally, section 6 gives some conclusion and future expectations.

\section{1969, Informatics Institute. Official Certification, Out of the University}

At this time, after 30 years under the Franco's dictatorship, the centralism in the administration was very strong. Informatics as a body of knowledge was not included in 
the University. There were some courses in different studies like the Universidad Complutense de Madrid that had an Automatic Computation specialty with some courses on the basic computer architecture and on programming, common to the curricula on Mathematics and Physics, and the Industrial Engineering Schools that had a course on Computers in which was mainly explained the basic von Neumann architecture and the FORTRAN language. In March of this year, the MEC decided to create in Madrid the Instituto de Informática [16] directly depending of the MEC. This institute had strange organization, without any contact with the university and following a strange curriculum: the students earned a different diploma after each one of the five years of studies after the secondary education [17].

- Programador de aplicaciones (Applications programmer)

- Programador de sistemas (Systems programmer)

- Analista de aplicaciones (Applications analyst)

- Analista de sistemas (Systems analyst)

- Técnico de sistemas (Systems engineer)

The first two levels had compulsory courses but in the other three there were three specialties: fundamental informatics, business management informatics and physical systems. The specialties of fundamental informatics and business management informatics had at the applications analyst, systems analyst and systems engineer optional courses chosen in both cases among the same set of courses mainly oriented to applications and not to fundamental informatics. With these degrees it was intended that people who earned them were ready to develop professional tasks in industry and companies. It is easy to understand the difficulties of simultaneously giving a solid back-ground and the practical knowledge associated to each degree. The Informatics Institute started its courses in 1970.

In 1971 the II created a delegation in San Sebastián that was obliged to follow the same curriculum and also without any contact with the University. In 1972, the Universitat Autònoma de Barcelona (UAB) succeeded to create in its Faculty of Sciences an Informatics Department. It decided to start teaching Informatics in this Faculty as a 5 years curriculum with a typical university structure, but rapidly the II reacted and obliged the UAB to follow the same curriculum in its teaching. However, the team that started to teach Informatics at the UAB was a mixture of good professionals and people having followed some university computer courses, mainly in France (Paris and Grenoble); they kept the course titles of the official curriculum but they tried to transform the contents into a more reasonable structure according the university spirit. Criterion in this period: Centralism that is all centers teaching informatics should follow the same curriculum, at least formally. The idea of giving a professional diploma each year avoided the possibility of a good theoretical basis before giving the application knowledge. 
Table 1. Informatics Institute. Degrees, courses and teaching hours

\begin{tabular}{|c|c|c|c|c|c|}
\hline Diploma & $\begin{array}{l}\text { Compulsory } \\
\text { courses }\end{array}$ & $\begin{array}{l}\text { Compulsory } \\
\text { teaching } \\
\text { (hours) } \\
\end{array}$ & $\begin{array}{l}\text { Optional } \\
\text { courses }\end{array}$ & $\begin{array}{l}\text { Optional } \\
\text { teaching } \\
\text { (hours) }\end{array}$ & $\begin{array}{l}\text { Total } \\
\text { teaching } \\
\text { (hours) }\end{array}$ \\
\hline $\begin{array}{l}\text { Applications } \\
\text { programmer }\end{array}$ & 4 & 750 & 0 & 0 & 750 \\
\hline $\begin{array}{l}\text { Systems pro- } \\
\text { grammer }\end{array}$ & 6 & 750 & 0 & 0 & 750 \\
\hline $\begin{array}{l}\text { Systems analyst: } \\
\text { Fundamental } \\
\text { informatics }\end{array}$ & 6 & 690 & $1 / 3$ & 90 & 780 \\
\hline $\begin{array}{l}\text { Applications } \\
\text { analyst: Business } \\
\text { Management } \\
\text { Informatics }\end{array}$ & 6 & 690 & $1 / 3$ & 90 & 780 \\
\hline $\begin{array}{l}\text { Applications } \\
\text { analyst: Physical } \\
\text { systems } \\
\end{array}$ & 6 & 770 & 0 & 0 & 770 \\
\hline $\begin{array}{l}\text { Systems analyst: } \\
\text { Fundamental } \\
\text { informatics }\end{array}$ & 3 & 570 & $2 / 3$ & 180 & 750 \\
\hline $\begin{array}{l}\text { Systems analyst: } \\
\text { Business Man- } \\
\text { agement Informat- } \\
\text { ics }\end{array}$ & 4 & 660 & $1 / 3$ & 90 & 750 \\
\hline $\begin{array}{l}\text { Systems analyst: } \\
\text { Physical systems }\end{array}$ & 5 & 750 & 0 & 0 & 750 \\
\hline $\begin{array}{l}\text { Systems engineer: } \\
\text { Fundamental } \\
\text { informatics }\end{array}$ & 3 & 480 & $3 / 6$ & 270 & 750 \\
\hline $\begin{array}{l}\text { Systems engineer: } \\
\text { Business Man- } \\
\text { agement Informat- } \\
\text { ics }\end{array}$ & 4 & 570 & $2 / 6$ & 180 & 750 \\
\hline $\begin{array}{l}\text { Systems engineer: } \\
\text { Physical systems }\end{array}$ & 5 & 690 & 0 & 0 & 690 \\
\hline
\end{tabular}

\section{1976, the First University Degrees in Informatics}

In 1974, the MEC considered that Informatics had to be included in the regular university teaching structure. A commission was created to study how to pass the Informatics Institute and its satellites to the university. Several universities fight in this commission to get the informatics studies. Finally by the end of 1975 (the decision was published by the MEC early 1976) was decided that three Faculties of Informatics had to be created in Barcelona (in the Universitat Politècnica de Catalunya, UPC), in San Sebastián (in the Euskal Herriko Unibertsitatea, EHU) and in Madrid (in the Universidad Politécnica de Madrid, UPM), and that the previous institutions giving informatics studies had to stop to teach informatics [18]. This was true in Madrid and 
San Sebastián because the Informatics Institute and its delegation were incorporated to the corresponding universities and their denomination changed. In Barcelona the situation was more complicated because it was necessary to passing studies from one university to another (unbelievable in Spain at that time). Finally, both universities kept their studies. The new Faculties started to work in October 1977 with a five year curriculum that, for the first time in Spain, was different for each university but approved by the MEC. In addition, in the Faculty of Barcelona the classical curriculum structure of a fixed set of courses per academic year was broken and the curriculum was organized by courses with their corresponding pre-requisites in such a way that the student was able to organize his/her own curriculum choosing courses among those offered by the Faculty but respecting some compulsory courses [19] and the student had the right to earn his/her diploma when they had cumulated an established number of credits. This curriculum was deeply inspired by the ACM Computing Curriculum 1968 [5]. A draft version of this curriculum can be found in [30]. In all cases curricula were planned for five years of studies. Curricula of the Madrid and San Sebastian Faculties followed the traditional structure but also inspired by the ACM Computer Curriculum 1968 [19].

The students that successfully followed the studies in one of these universities obtained the title of Licenciado en Informática (Licensed in Informatics).

Criterion in this period: Centralism because the curricula should be approved by the MEC but, for the first time in Spain, each centre was following a different curriculum proposed without any guidelines and the MEC delivering the same diploma. These curricula were proposed, according the university interests and the possibilities of their teaching staff. Around 1980 a new 3-years study in Informatics was created and started in Madrid (UPM) and Valencia (Universitat Politècnica de València). The students that successfully followed these studies obtained the title of Diplomado en Informática (Diplomate in Informatics). Few after the Universidad de Las Palmas de Gran Canaria and the Universistat de les Illes Balears (Palma de Mallorca) created 3years studies in Informatics. When these studies in Valencia, Las Palmas and Palma de Mallorca arrived to the third year, extensions to 5-years were implemented in these three universities. These three years studies had two orientations or intensifications, common to all centers, derived from the specialties of the Informatics Institute:

- Computer systems mainly devoted to a vision of the computer under the user interface.

- Business management applications mainly devoted to the computer over the user interface.

\section{1992, Informatics Engineering}

By the late 1980s, the MEC started a general reorganization of all university studies creating a catalogue of official titles (those delivered by the MEC itself based on the studies done in some university) reorganizing the existing titles and creating new ones. To get the official acceptance by the MEC each one of these titles had to respect a set of contents established by the MEC (main topics). To describe the relative 
importance of each of these topics a measure was invented: the credit equivalent to ten hours of teaching (including all kind of activities driven by the university teaching staff: theoretical classes, practical classes, etc.) received by the students. An academic year was estimated to have 30 weeks. Each university wishing to deliver some diploma had to submit a curriculum proposal that was controlled by the MEC itself in order to check if the compulsory main topics were correctly covered.

In the case of informatics three new titles were created and those existing till that moment disappeared:

- Ingeniero en Informática (Informatics Engineer): 5-years divided in two cycles and between 300 and 400 credits [20].

- Ingeniero Técnico en Informática de Sistemas (Technical Engineer in Informatics: Computer systems orientation): 3-years and between 180 and 225 credits [21].

- Ingeniero Técnico en Informática de Gestión (Technical Engineer in Informatics: Computer business management orientation): 3-years and between 180 and 225 credits [22].

Also it was stated that the students having earned one of these 3-years degrees were allowed to follow the second cycle of Ingeniero en Informática. In the early years of this decade all universities giving the old degrees in informatics adapted their curricula to the new characteristics and other universities started to teach informatics with this new orientation. This adaptation took different solutions:

- Universities that delivered the three degrees separately: the 5-years degree in a faculty or school and the 3-years degree in a different school.

- Universities that delivered the three degrees in the same faculty or school with a complete implementation of the three degrees.

- Universities that delivered the three degrees in the same faculty or school but without the implementation of the first cycle of Ingeniero en Informática and using both 3-years degrees as the first cycle.

- Universities that had just the 5-years degree.

- Universities that had one or both 3-years degrees

However, soon several problems appeared:

- The fact that three different first cycles gave access to the second cycle introduced difficulties in different topics like networks, computer architecture and software engineering. The reasons were that sometimes the same main topic with the same descriptors had assigned different number of credits or that the student coming from some first cycle had a previous knowledge of some topic unknown for the students coming from other first cycles.

- The low number of credits assigned to operating systems (6) that obliged to most of universities to create supplementary courses in this topic.

- The growing importance of networking. It was possible that an Ingeniero Técnico en Informática de Gestión could earn his/her title with no knowledge on networking. 
- The inconvenience of having Automata theory as a compulsory topic in the first cycle of Ingeniero en Informática (too theoretical for beginners) and in Ingeniero Técnico en Informática de Sistemas (too theoretical for the applied orientation of the 3-years studies).

During this period the number of faculties and schools delivering these degrees was continuously increasing (and currently there are approximately 80 in Spain). This fact and the need of exchanging information about experiences and discussing about the difficulties in the implementation of their curricula provoked the need of discussion meetings with the participation of all faculties and schools teaching informatics careers. These annual meetings started in 1995. However, as the number of schools and faculties was continuously increasing, in 1998 it was decided to set up a minimal organization for these meetings, with a president and a secretary and a title: CODDI. The first task assigned just after the appointment of a president was the review of the main topics of the informatics careers in order to correct the detected inconveniences. CODDI submitted this proposal to the MEC. However, it was not accepted by the MEC because the acceptation would have allowed other studies to request also the modification of their compulsory main topics. And this would have introduced a high degree of discussions between universities and between these ones and the MEC. Nevertheless, this proposal was accepted for the new informatics curricula as guidelines for the analysis and acceptation of future curricula submitted to the MEC by the universities.

Criteria: The degree of freedom in the creation of new university curricula was reduced. The names of the diplomas were fixed by the MEC and these diplomas were delivered by the MEC following the university proposal when a student had successfully passed all courses. Each university curriculum could be different.

\section{$5 \quad 2010$, European Computer People}

\subsection{Adaptation to the EHES}

In coincidence with the change of millennium, the European Union decided ask the member states to reorganize their university systems in such a way that a convergence was reached around 2010 in two main points:

- University studies should be organized in three levels: bachelor, master and doctorate.

- University studies should define for each course the effort required to the student, the European Credit Transfer System (ECTS), equivalent, approximately to 25 to 30 hours of work for the student including all his/her activities (theoretical courses, practical courses, seminars, personal study, exam preparation, etc.).

This convergence was named as the Bologna process because the agreement of all the member states was reached in a meeting held in the city where the first European university was created. 
In 2001 CODDI started a volunteer work on how to adapt the informatics studies to this convergence process. Initially a set of considerations showing mismatches in either the university studies structure or in the consideration by the society of the degrees delivered by the university [12]. Later in 2003 CODDI started an economically funded that confirmed the conclusions of the previous one [2].

Several changes in the MEC delayed the implementation of the EHES. Finally in 2007 the framework for the implementation of the EHES was set up [23]. Some points were clear but the framework was not yet complete:

- There would not be a catalogue of official titles; each university had to propose its own titles that would be validated by an independent agency (Agencia Nacional de Evaluación de la Calidad del Sistema Universitario, ANECA, National Agency for the Evaluation of the Quality of the University System) that would evaluate the appropriateness of the proposed title (specially avoiding confusion to the society), the quality of the proposal and the existence of a sufficient amount of the human and material resources allocated to the correct implementation.

- The Grado (Bachelor), in our case of Ingeniero en Informática, would have 240 ECTS that would include an end of studies project.

- The Master degree would have 60 or 120 ECTS depending on the coherence between the grade earned and the intended Master and including an end of Master project.

The proposal of the CODDI, several years before the decisions of the MEC, was fully in line with the framework in which the universities will work in the following years.

Early 2008 five commissions were set up to analyse the new curricula on Science, Engineering, Health, Law and Economics, and Letters and Humanities. Informatics was included in the engineering domain.

In order to understand the environment, it is necessary to know that all classical engineering studies (agronomical engineers, aeronautical engineers, civil engineers, forest engineers, industrial engineers, mining engineers, naval engineers and telecommunication engineers) have exclusive professional capabilities and differentiated by branch and level (3-years or 5-years of studies) and associated only to the academic diploma. This organization causes serious conflicts of interests in which are involved the corresponding professional associations. The informatics engineers have no defined professional capabilities and their professional space is frequently invaded by other engineering branches, mainly the industrial and telecommunication engineers.

Traditional engineering associations were against the decision of the government of associating professional capabilities to the Grado diploma when there were different capabilities for diplomas of 3 and 5 years. Before solving this fight, the verification process started in March 2008. This process was theoretically very wellconceived but looking more to how to teach than what should be taught. However, there were terms not clearly defined, related between them and critical for the correctness of this process, like: objectives, competencies, modules, matters, courses, contents, learning outcomes, etc. 
The verification commissions started to work with a formal description of its work but with an important lack of definitions (as explained before) and fundamental and logistic problems. Among the last ones an important difficulty was the lack of a good management system of the proposals. Due to the lack a good definition of its task, commission members used their better knowledge to the proposals analyses.

Two points were taken especially into account:

- The name of the title should represent the delivered contents.

- The title description should not induce into error the future students reading the document with the intention of following these studies.

However, as classical engineering studies had associated professional capabilities supported by the corresponding professional associations, it soon appeared the need of defining the objectives and competencies of these studies. To solve this problem the MEC published in February 2009 these characteristics for all classical engineering studies making the equivalence of the Grado with the 3-years engineers and their capabilities and the Master with the 5-years engineers and their capabilities. However the definitions objectives and competencies of these studies were not an example of well doing because:

- The objectives were defined in terms of competencies.

- The competencies were defined in terms of teaching contents.

Also, this decision was against the previous definition in which the Grado gave the professional capabilities and the Master gave the specialization. With this decision the Grado gave the professional capabilities of the 3-years engineers in its concrete specialties and after obtaining the Master they got all the professional capabilities of 5years engineers. This approach has the inconvenience (detected by the CODDI with respect the previous Informatics studies) of passing from a specialized knowledge to a general one.

In the case of Informatics Engineering and some other newly created they had not professional capabilities, this fact represented to place them in a level lower than the classical engineers and the CODDI fight to have at least a definition of its studies similar to the other engineering studies even if they had not professional capabilities. This was obtained in August 2009 when the MEC published the definition of objectives and competencies for the Grado and Master in Informatics Engineering [24] with a better conception avoiding the definition of objectives in terms of competencies and the competencies in terms of teaching contents. This definition included the five specific technologies defined in the ACM/IEEE-CS Computing Curricula [1] in a similar way to the other classical engineers that all of them had several specialties:

- Computer Engineering

- Software Engineering

- Computing

- Information Systems

- Information Technology 
These specific technologies are different in its competencies but have the same objectives. The competencies structure is the following:

- Module of basic knowledge: 60 ECTS

- Module common to the informatics branch: 60 ECTS

- Specific technology module: 48 ECTS, different for each specific technology

- End of Grado project: 12 ECTS

The rest until 240 ECTS is at disposal of the University for strengthening the above mentioned topics or others, for stages in companies and for collateral activities.

With the existing degree of freedom for defining the title of the Grado, two alternatives were presented to the Universities:

- To propose a unique name with several technological specialties (or professions with professional capabilities, if any)

- To propose one or several names related to the technological specialties (or professions with professional capabilities) they want to develop.

In favour to independent titles for each specific technology or profession with recognized capabilities there are to be aligned with these professions and to use socially recognized names. Instead, for a unique title with technological specialities there are the limitations imposed by the local governments concerning the number of careers they were ready to fund, to be aligned with the White Book recommendations and to find the social recognition.

In order to avoid misunderstandings of the future students the criteria followed by the verification commission was to accept a specific name if it was adapted to a specific technology (e.g. Software Engineer) and a generic name (e.g. Informatics Engineer) in the case of including several specific technologies.

Criteria: The degree of freedom in the creation of new university curricula was maintained or increased. The names of the diplomas were fixed by the universities and these diplomas were also delivered by the universities who have the responsibility on the quality of the delivered diploma. Each university curriculum could be different.

\subsection{Results of the Adaptation to the EHES}

New computer careers are currently in their first years of implementation considering that the starting academic year was between 2008-09 and 2010-11. There is some uniformity after the definition of objectives and competencies of the Grado en Ingeniería Informática. The curricula verified previously to this definition have quite different structures. To access the details of these studies, one can access the Registro de Universidades, Centros y Títulos, RUCT, (Register of Universities, Centres and Degrees, RUCT) [25].

At present we find:

- 57 studies of Grado en Ingeniería Informática, of which 8 were verified before the definition of the objectives and competencies; those verified based in this definition should have, at least, two specific technologies but most of them have 
the five defined specific technologies, although, maybe for economic restrictions, they are not running all of them.

- 7 curricula of computer engineering, according with the corresponding specific technology.

- 8 curricula of information systems, according with the corresponding specific technology.

- 7 curricula of software engineering, according with the corresponding specific technology.

- 7 curricula of information technology, according with the corresponding specific technology.

- 1 curriculum of systems engineering, that is not in accordance with the defined specific technologies.

However, the adaptation of informatics studies (and most of the university curricula has been done without the adequate preparation for teachers to assume changes involving the adaptation to the EHES: the change from a paradigm based on the teaching effort of professors to another based on the learning effort of students with the modifications involved both at teaching infrastructure (decrease in large amphitheaters and increase in small rooms for seminars, spaces for study and group work of the students, increased laboratories, etc.) as well as the teachers task and dedication to follow the students learning process and to coordinating with other teachers of the same course to achieve a reasonably uniform weekly workload. Also some universities have proposed curricula that we can consider in the informatics domain but with different orientations and contents and without professional capabilities. Among them we can find:

- 6 curricula of Grado en Ingeniería Multimedia (Multimedia engineering), habitually composed by a third of informatics, a third of telecommunications and a final third of content generation.

- 8 curricula of Grado en Ingeniera Biomédica (Biomedical Engineering)

- 1 curriculum of Grado en Informática y Servicios (Informatics and Services)

- 1 curriculum of Grado en Fotografía y Creación Digital (Photography and Digital Creation)

- 1 curriculum of Grado en Ingeniería en Organización de las Tecnologías de la Información y de la Comunicación (Information and Communication Organization Engineering)

- 1 curriculum of Grado en Ingeniería de Sistemas TIC (ICT Systems Engineering)

- 1 curriculum of Grado en Matemática Computacional (Computational Mathematics)

- 1 curriculum of Grado en Matemáticas e Informática (Mathematics and Informatics)

- 1 curriculum of Grado en Ingeniería en Desarrollo de Contenidos Digitales (Digital Contents Development Engineering)

- 1 curriculum of Grado en Diseñoo y Desarrollo de Videojuegos (Videogames Design and Development) 


\subsection{Coming Steps}

\section{Follow Up Process}

To prevent that the accreditation process discover that the implementation of curricula have not been made in accordance with the proposal made by the university, ANECA has proposed a monitoring process two years after the implementation of some curriculum and to be repeat every two years. The objective of this exercise is to analyze how the curriculum implementation has been carried out and inform universities about missing or not correctly implemented aspects, especially with regard to the procedures to ensure the quality of the educational process. These procedures are generally new to the universities and should ensure the new orientation of the teaching given by the Bologna agreement. The follow up process has been structured in the following way:

- Universities should not submit any documentation; they should only give access to the responsible people for monitoring the information university system so that they can see how the points proposed in the verification report have been implemented.

- From these observations a report is issued that allows the university to have an external and impartial view of its performance.

\section{Accreditation Process}

The accreditation process has been scheduled to be performed six years after the implementation of any new curriculum. However, there is still nothing defined: Neither by whom, nor how it will be done.

\section{Conclusion}

We have presented a short overview of the different criteria used in the university environment for setting up the computer education in Spain. To sum up:

- The story began by 1969 , with the creation of the Informatics Institute, we have described a period of centralism. All centers which teaching informatics followed the same curriculum, at least formally. The idea of giving a professional diploma each year avoided the possibility of a good theoretical basis before giving the application knowledge.

- Next step, by 1976, three universities began to develop a Computer Science curricula. It was still an age of centralism as long as curricula have to be approved in Madrid by MEC, but for the first time in Spain each University centre could follow a different curriculum proposed without any guidelines and MEC delivered the same diploma. These curricula were proposed, according the university interests and the possibilities of their teaching staff.

- By the late 1980s the MEC started a general reorganization of all university studies. In the case of computer science it implied a reduction in the degree of creation freedom of new university curricula. The names of the diplomas, fixed 
by MEC, passed from the old Licenciado (Licensed), a term associated to base sciences (like Mathematics, Chemistry or Physics) to the new Ingeniero (Engineer) a term associated to applied sciences. However, there was no such change in the curricula and the balance among computer science and computer engineering matters remained almost the same.

- Eventually, by 2000, the European Union decided to reorganize the member states' university systems in such a way that a convergence was reached around 2010. It was the so-called European Higher Education Space (EHES). Convergence had two folds. On the one hand, University studies should be organized in three levels: bachelor, master and doctorate. On the other hand, University studies should define for each course the effort required to the student, the European Credit Transfer System (ECTS), equivalent, approximately to 25 to 30 hours of work for the student including all his/her activities (theoretical courses, practical courses, seminars, personal study, exam preparation, etc.). Once again, we want to evaluate the implementation criteria. In this case, the degree of freedom in the creation of new university curricula was maintained or increased. The names of the diplomas were fixed by the universities and these diplomas were also delivered by the universities who have the responsibility on the quality of the delivered diploma. Each university curriculum could be different.

How will the future be? We think it will be necessary to wait ten years until we will be able to have an opinion about the success of this reform, mainly to evaluate how professors and students have changed their teaching and learning habits. This is, may be, the strongest challenge of this reform.

Acknowledgements. This work has been partially funded by the Spanish Ministry of Science and Innovation and the European Union FEDER funds, both in the framework of the project TIN2011-23889, Eficiencia Energética, Virtualización y Rendimiento de Servidores.

\section{References}

1. ACM/IEEE-CS: Computer science curriculum. Tech. rep., Report from the Interim ReviewTask Force (2008), http: / / www.acm.org/education/curricula/ComputerScience2 008 . paf

2. Casanovas, J., et al.: Libro Blanco sobre las titulaciones universitarias de informática en el nuevo espacio europeo de educación superior. ANECA (2004)

3. Arroyo, L.: 200 años de informática. Espasa Calpe, Madrid (1991)

4. Aspray, W.: Was early entry a competitive advantage? US universities that entered computing in the 1940s. IEEE Annals of the History of Computing 22(3), 42-87 (2000)

5. Atchison, W.F., Conte, S.D., Hamblen, J.W., Hull, T.E., Keenan, T.A., Kehl, W.B., McCluskey, E.J., Navarro, S.O., Rheinboldt, W.C., Schweppe, E.J., Viavant, W., Young Jr., D.M.: Curriculum 68: Recommendations for academic programs in computer science: A report of the ACM curriculum committee on computer science. Commun. ACM 11(3), 151-197 (1968), http: //doi.acm.org/10.1145/362929.362976 
6. Clark, M.: State support for the expansion of UK University computing in the 1950s. IEEE Annals of the History of Computing 32(1), 23-33 (2010)

7. De Diego García, E.: Historia de la industria en España: la electrónica y la informática. Escuela de Organización Industrial, Madrid (1995)

8. Ensmenger, N.L.: The Computer Boys Take Over: Computers, Programmers, and the Politics of Technical Expertise. MIT Press, Cambridge (2010)

9. Fornes, J.: Los físicos en la facultad de informática de Barcelona, 1976-1992. Actesd'Història de la Ciència i de la Tècnica 5, 71-82 (2012)

10. Fornes, J., Herran, N.: Computing in transition: the origins of Barcelona's school of informatics, 1976-1984. IEEE Annals of theHistory of Computing 36(1), 18-29 (2014)

11. Galán, L.: 100 años de informática y telecomunicaciones: España siglo XX. Cuadernos de Historia de las Telecomunicaciones, Fundación Rogelio Segovia para el Desarrollo de las Telecomunicaciones (2005),

http: / / books.google.es/books?id=P3i1AAAACAAJ

12. Campos, J.C., et al.: Informe sobre la adaptación de los estudios de TIC a la declaración de Bolonia. Tech. rep., unpublished document (For getting it, contact R. Puigjaner) (2002)

13. López García, A.: Introducció a la història de la informàtica en Espanya. Projecte Final de Carrera-UPC, dirigit per Miquel Barceló (2002)

14. López García, S.: El doble tañido del hierro: El tecnólogo José García Santesmases. In: Actes de les I Trobades d'Història de la Ciència i de la Tècnica, pp. 255-262. Societat Catalana d'Història de la Ciència i la Tècnica, Barcelona (1994)

15. López Garcóa, S.: Los precedentes de la informática y la automática en España (19251971). In: Tècnica i societat en el món contemporani, pp. 255-262. Museu d'Història de Sabadell, Sabadell (1994)

16. M.E.C.: Decreto 554/1969. BOE de 14/04/1969 - Sección I (March 1969), de 29 de marzo (Educación y Ciencia), por el que se crea un Instituto de Informática, dependiente del Ministerio de Educación y Ciencia, con sede en Madrid, y se regulan las enseõanzas del mismo

17. M.E.C.: Orden de 24 de junio de 1971. BOE de3/07/1971 (June 1971), por la que se aprueba el Plan de Estudios del curso de Programador de aplicaciones, Programador de Sistemas, Analista de Aplicaciones, Analista de Sistemas y Técnico de Sistemas

18. M.E.C.: Decreto 593/1976. BOE de 26/03/1976 - Sección I (March 1976), de 4 de marzo, por el que se crean Facultades de Informática en Barcelona, Madrid y San Sebastián

19. M.E.C.: Orden de 7 de junio de 1977. BOE de 27/07/1977 - Sección I (June 1977), por la que se aprueba el plan de estudios de la Facultad de Informática de Barcelona

20. M.E.C.: Real decreto 1459/1990. BOE de 20/11/1990 - Sección I (October 1990), de 26 de octubre, por el que se establece el título universitario oficial de Ingeniero en Informática y las directrices generales propias de los planes de estudios conducentes a la obtención de aquél

21. M.E.C.: Real decreto 1459/1990. BOE de 20/11/1990 - Sección I (October 1990), de 26 de octubre, por el que se establece eltítulo universitario oficial de Ingeniero Técnico en Informática de Sistemas y las directrices generales propias de los planes de estudios conducentes a la obtención de aquél

22. M.E.C.: Real decreto 1459/1990. BOE de 20/11/1990 - Sección I (October 1990), de 26 de octubre, por el que se establece el título universitario oficial de Ingeniero Técnico en Informática de Gestión y las directrices generales propias de los planes de estudios conducentes a la obtención de aquél

23. M.E.C.: Real decreto 1393/2007. BOE de 30/10/2007 - Sección I (October 2007), de 29 de octubre, por el que se establece la ordenación de las enseñanzas universitarias oficiales 
24. M.E.C.: Resolución de 8 de junio de 2009. BOE de 4/08/2009 - Sección III (June 2009), de la Secretaría General de Universidades, por la que se da publicidad al Acuerdo del Consejo de Universidades, por el que se establecen recomendaciones para la propuesta por las universidades de memorias de solicitud de títulos oficiales en los ámbitos de la Ingeniería Informática, Ingeniería Técnica Informática e Ingeniería Química

25. M.E.C.D.: Registro de universidades, centros y títulos (RUCT), Registro de Universidades, Centros y Títulos (RUCT) (accessed on June 18, 2013)

26. Mounier-Kuhn, P.: L'Informatique en France de la seconde guerre mondiale au Plan Calcul. L'Émergence d'une science (Informatics in France from World War II to Plan Calcul: The Emergence of a Science). Presses de l'Université Paris-Sorbonne (2010)

27. Mounier-Kuhn, P.: Computer science in French universities: Early entrants and late comers. Information and Culture 47, 414-456 (2012)

28. Nonell, R. (ed.): 25 anys de la Facultatd'Informàtica de Barcelona. UPC, Barcelona (2002), http: / /www. fib.upc. edu/25e/llibres.htm

29. Presidencia del Gobierno: La informática en España 1976. Servicio central de informática, servicio central de publicaciones, Madrid (1977)

30. Puigjaner, R., Vergés, M.: Bases para un plan de estudios. NOVATICA (5) (1975)

31. Randell, B.: From analytical engine to electronic digital computer: The contributions of Ludgate, Torres, and Bush. Annals of the History of Computing 4(4), 327-341 (1982)

32. Sales, T.: La informática comercial española en la primera década (1960-1970): Apuntes para una historia de la informática en España. Novatica (34), 53 (1980)

33. Samet, P.A.: The evolution of computer science teaching and research in the UK. In: Computers in Europe. Past, Present and Future, Kyiv, October 5-9 (1998), http: / /www. icfcst.kiev. ua/SYMPOSIUM/Proceedings/Samet.pdf

34. Yuste, A., Palma, M.: Scanning our past from Madrid: Leonardo Torres Quevedo. Proceedings of the IEEE 93(7), 1379-1382 (2005) 